\title{
An Account of Generous Action and Esteem in Pāli Buddhism
}

Nicholaos JONES

Nicholaos JONES is professor of Philosophy at The University of Alabama in Huntsville. His research relating to Buddhism focuses mainly on metaphysics in the medieval Huayan tradition of Chinese Buddhism. His research has been published in Asian Philosophy, British Journal for the History of Philosophy, Comparative Philosophy, Dao, Journal of Chinese Philosophy, and Philosophy East and West, among other places. He is currently writing a book on models and metaphors in the work of Fazang, third patriarch of the Huayan tradition.

Email: nick.jones@uah.edu

International Journal of Buddhist Thought \& Culture Vol. 30. No.2 (December 2020): 195-225

(C) 2020 Academy of Buddhist Studies, Dongguk University, Korea

https://doi.org/10.16893/JJBTC.2020.12.31.2.195

The day of submission: 2020.9.13.

Completion of review: 2020.11.17.

Final decision for acceptance: 2020.12.14. 


\begin{abstract}
I propose an account of generous action in the Pāli Buddhist tradition, whereby generous actions are instances of giving in which the donor has esteem for the recipient of their giving. The account differs from recent Anglophone accounts of generous action. These tend to construe generous actions as instances of a donor freely offering a gift to the recipient for the sake of benefiting the recipient. Unlike the Buddhist account I propose, these accounts do not require donors to esteem their recipient. Accordingly, I also offer a partial account of esteem, whereby one esteems another only if they refrain from noticing the other's faults and they encounter the other as someone who is superior in virtue and goodness. Taken together, the Buddhist accounts of generous action and esteem offer insight into certain ways in which different philosophical traditions tend to characterize generous action.
\end{abstract}

Key words: esteem, generosity, gift, karma, merit, no-self 


\section{Introduction}

Generosity marks the beginnings of Buddhism. In the Discourse About Kassapa (Kassapa Sutta, Ud 3.7), Mahākassapa, one of the Buddha's first disciples, is recovering from an illness. During a walk to collect alms, he encounters a weaver. The weaver has been searching for Mahākassapa. Upon guiding the monk to his home, the weaver offers a bowl filled with curried rice. Mahākassapa, discerning that the weaver is an embodiment of the mighty god Indra, and having refused alms from lesser gods earlier in the morning, requests that Indra abstain from giving future offerings. Indra replies that even the gods have a duty (P. karaniiya) to make merit (P. puñña). ${ }^{1}$ Then, after praising the monk and beginning his ascent to his heavenly abode, Indra declares that Mahākassapa is the best recipient for giving (Ireland 1997, 44-45).

Early Vedic tradition depicts Indra as the origin and sustenance of all things (Rig Veda 2.12.7; recited from Perry 1885, 182). Following Indra's demotion in subsequent Vedic tradition, Buddhist tradition effectively adopts Indra as a divine disciple of the Buddha. For example, the Discourse on the Grounds of Merit-Making (Puñnakiriyavatthu Sutta, AN 8.36) depicts Indra as a convert to Buddhist teaching who excels in meritorious giving (Bodhi 2012,1171). Citing as evidence some instructions about giving that the Buddha offers to Indra, Points of Controversy (Kathavatthu) concludes that giving to the sangha (Buddhist community) is exceptionally meritorious (Kathãvatthu 17.9; recited from Aung and Rhys Davids 1915, 320-321). Assuming that Indra takes the Buddha's instructions to heart, a likely basis for Indra's esteem toward Mahākassapa is Mahākassapa's instrumental role in helping to establish the saingha.

The Discourse About Kassapa positions generous action as a foundation for a Buddhist community. This is an intelligible position, insofar as Buddhist monks take a vow of poverty. Alms-giving sustains the monastic community. Indra's remark about having a duty to make merit is somewhat less intelligible. Contemporary Anglophone philosophical assessments of generosity tend to agree that generous action is supererogatory, good but not obligatory (see Hunt 1975, 239; Miller 2018, 227). They tend to agree, as well, that actions are generous only when their primary motive is altruistic, directed toward benefitting the recipient for their own sake and without an expectation of personal benefit to the giver (see Hunt 1975, 239; Miller 2018, 225). Indra's remark seems to violate both of these constraints on generous action. Yet Indra's alms-giving to 
Mahākassapa is a paradigm of generous action in the Buddhist tradition.

A successful account of generous action in the Buddhist tradition should explain why generous actions have the characteristics Buddhist tradition ascribes to them. The account should identify a relatively sparse collection of conditions on generous action, from which the characteristics of generous actions are derivable, and for which there is textual support from the Buddhist tradition. The conditions should help in distinguishing generous actions from other acts of exchange such as barter, charity, and justice. They also should help with identifying anything that is distinctive about the Buddhist approach in conceptualizing generous action, in comparison with approaches from other, non-Buddhist traditions.

Despite its centrality to Buddhist community, no such account is explicit in Buddhist discourses, treatises, or commentaries. I propose, accordingly, to develop an account of generous action in the Buddhist tradition. The account engages with recent interest shown in generosity by sociologists and analytic philosophers (see Herzog and Price 2016; Miller 2018). It also complements more general examinations of virtue in Buddhist ethics (such as Keown 1992; Wright 2009; Goodman 2015; MacKenzie 2018). I focus on generous action rather than generosity, or the disposition toward generous action (P. cāga), because this focus helps "to pave the way to developing an account of the virtuous character dispositions that are capable of giving rise to such acts" (Miller 2018, 217). Moreover, because the Buddhist tradition is long and diverse, I focus on the conception of generous action that appears in the various scriptural collections (P. nikäas) of the early Pāli canon-albeit with some occasional reference to later or less canonical works. For the sake of expository convenience, I thereby refer to the proposed account of generous action as an account of generous action in the Pāli Buddhist tradition.

\section{Conditions of Generous Action}

I propose that generous actions in the Pāli Buddhist tradition are instances of giving in which the donor has esteem for the recipient of their giving. I elaborate upon this proposal in this section by dividing it into two conditions on generous action, with textual evidence from the Pāli Buddhist tradition for each condition, and developing a partial analysis of the second (esteem-based) 
condition. In subsequent sections, I use the proposal to explain the value of generous action, examine its implications for teachings about merit and noself, and highlight differences with accounts of generous action from other traditions.

The account I propose contains two fundamental conditions. The first is labelled the Giving Constraint.

Giving Constraint: All generous actions involve giving (P./Skt. dāna; Ch. bushi 布施).

According to the Discourse on Giving (Dāna Sutta, AN 7.49) in The Buddha's Sayings (Itivuttaka 98), that which is given may be material or soteriological.

Bhikkhus, there are these two kinds of giving: the giving of material things and the giving of the Dhamma. (Ireland 1997, 192)

Indra's offering of rice exemplifies giving of the material; the Buddha's instruction to Indra, giving of the soteriological. Whatever the offering, generous action always involves some transfer from a donor to a recipient. The best confirmation for the Giving Constraint on generous action, however, is linguistic rather than textual: the standard Buddhist term for denoting generous action means giving.

Despite the intimate connection between generous action and giving, the Pāli Buddhist tradition tends to restrict generous actions to only certain sorts of giving. The relevant restrictions support a second condition on generous action. The second condition is labelled the Esteem Constraint.

Esteem Constraint: All generous actions involve the donor having esteem (P. saddhä; Skt. śraddhä; Ch. xin 信) for the recipient.

The term esteem denotes an attitude of trust and confidence. Esteeming someone, in a Buddhist sense, means encountering them as worthy of one's efforts. ${ }^{2}$

According to the Discourse About Velàma (Veläma Sutta, AN 9.20), giving attentively-viewing the recipient of giving as someone on whom one's efforts are likely to bear fruit-is superior to giving inattentively, viewing the recipient 
of giving as someone on whom one's efforts are likely to be wasted.

Are alms given in your family, householder?

Alms are given in my family, [Venerable Sir], but they consist of broken rice accompanied by gruel.

If, householder, one gives alms, coarse or excellent, and one gives disrespectfully, gives inconsiderately, does not give with one's own hand, gives what would be discarded, gives without a view of future consequences, then wherever the result of that gift is produced for one, one's mind does not incline toward the enjoyment of superb food, nor toward the enjoyment of superb clothing, nor toward the enjoyment of superb vehicles, nor toward the enjoyment of whatever is superb among the five objects of sensual pleasure. Also, one's children and wives, and one's slaves, servants, and workers, do not want to listen to one, do not lend an ear, and do not apply their minds to understand....

If, householder, one gives alms, whether coarse or excellent, and one gives respectfully, gives considerately, gives with one's own hand, gives what would not be discarded, gives with a view of future consequences, then wherever the result of that gift is produced for one, one's mind inclines toward the enjoyment of superb food, toward the enjoyment of superb clothing, toward the enjoyment of superb vehicles, toward the enjoyment of whatever is superb among the five objects of sensual pleasure. Also, one's children and wives, and one's slaves, servants, and workers, want to listen to one, lend an ear, and apply their minds to understand. (Bodhi 2012, 1274-1275)

The Esteem Constraint enshrines this superiority as the difference between giving that is generous and giving that is not. The constraint entails that, even if a donor gives to a recipient who is (objectively) worthy of esteem, the donor's giving is not generous unless the donor (subjectively) has esteem for the recipient. The constraint entails, as well, that giving to a recipient who is (objectively) unworthy of esteem does not preclude the giving from being generous.

The Esteem Constraint indicates that the donor's attitudes toward the recipients of giving determine whether instances of giving are generous. Two such attitudes are especially noteworthy as constraints on esteem. The first is Subjective Superiority. 
Subjective Superiority: An individual has esteem toward someone only if the individual (subjectively) encounters that someone as (objectively) superior in virtue and goodness. ${ }^{3}$

The Discourse on the Sick Person's Insight (Gilana-dassana Sutta, SN 41.10) illustrates Subjective Superiority. On the verge of death, the exemplary layperson Citta instructs his family to give everything available for donation, without reservation, to those who are virtuous (P. sìlavant) and good (P. kalyāna).

Whatever there may be in our family that can be given away, all that we will share unreservedly with the virtuous ones who are of good character. (Bodhi 2000b, 1331)

Virtuous and good individuals are worthy recipients (P. suppata). Their virtue and goodness incline them to use donations to good purpose. Since donations used to good purpose bear fruit, Subjective Superiority thereby explains why generous actions are directed toward the benefit of others.

Subjective Superiority admits comparative and categorical interpretations. On the comparative interpretation, when a donor encounters an individual as superior in virtue and goodness, the donor ranks the individual as more virtuous or good in comparison to the donor. On the categorical interpretation, by contrast, when a donor encounters an individual as superior in virtue and goodness, the donor judges the individual to qualify as virtuous or good, regardless of whether the individual is superior to the donor in virtue or goodness. (The difference between these interpretations is akin to the difference between judging someone to be wealthy because their ownings exceed one's own and judging someone to be wealthy because their ownings exceed some baseline standard for wealth.)

The Pāli Buddhist tradition is fairly neutral between these interpretations. The parable of Citta's generosity, in the Discourse on the Sick Person's Insight, presents Citta as someone who is virtuous and good, and it presents the intended recipients of his posthumous generosity - the Buddha and the sangha-as more virtuous and good than Citta. The Discourse on Eight Individuals (Pathama Atthapuggala Sutta, AN 8.59) identifies eight classes of worthy individuals, ranging from the stream-entrant (P. sotäpanna) at the beginning of Buddhist discipleship to the arabant at the end. 
Bhikkhus; these eight persons are worthy of gifts, worthy of hospitality, worthy of offerings, worthy of reverential salutation, an unsurpassed field of merit for the world. What eight? The stream-enterer, the one practicing for realization of the fruit of stream-entry; the once-returner, the one practicing for realization of the fruit of once-returning; the non-returner, the one practicing for realization of the fruit of non-returning; the arahant, the one practicing for realization of the fruit of arahantship. (Bodhi 2012, 1199)

The Pāli Buddhist tradition, however, does not limit worthy recipients to Buddhist monks and nuns. The Discourse to Vaccha (Vaccha Sutta, AN 3.57) declares that even stray animals qualify as worthy (see Bodhi 2012, 255). Similarly, in the Tale of the Hungry Tigress (Vyäghri-jätaka), a young princean incarnation of the Buddha-offers his body to sate a tigress on the verge of starvation (Ohnuma 2007, 278-80). None of these individuals qualifies as vicious or bad. Yet, according to the Compendium of Essence (Särasangaha), a collection of quotations by the thirteenth century Theravādin Siddhattha, "outcastes and fisherman who make their living by oppressing others" also qualify as worthy recipients of generous action (Heim 2004, 65). Insofar as those who live by oppressing others are neither virtuous nor good, there is some slight reason to favor the comparative interpretation of Subjective Superiority over the categorical interpretation.

Whatever its proper interpretation, Subjective Superiority is only a necessary condition for esteeming someone. It is not a sufficient condition. Just as a professional scientist might acknowledge their uneducated parents as superior in practical knowledge but inferior in scientific knowledge, a donor might encounter a recipient as superior in some virtues but inferior in others. The paradigmatic example is a layperson who acknowledges a monk as superior in their knowledge of Buddhist teachings and yet inferior owing to excessive greediness (or other misconduct). This sort of example motivates a second constraint on esteem. I label the constraint Selective Attention.

Selective Attention: Someone has esteem toward an individual only if they refrain from noticing the individual's faults.

The Compendium of Essence relates a story that illustrates Selective Attention. Knowing of a layperson who desires to make a gift, the local monastery sends 
a monk to receive the donation. The locals know that the monk is greedy. Yet, when the monk arrives, the layperson is reverential, honoring the monk and bestowing a generous gift. The monk later returns, seeking to borrow a shovel. The layperson lends the shovel, albeit rudely rather than reverentially. The layperson esteems the monk during the first encounter, attending to the monk as a representative of the saingha. During the second encounter, by contrast, the layperson attends to the monk's greedy nature and thereby lacks esteem toward the monk. ${ }^{4}$

Subjective Superiority and Selective Attention, as constraints on the nature of esteem, help to explain why generous actions always and only offer gifts. Were a donor to presume that a recipient would use their offering to benefit the donor, the donor would treat their offering as a transaction rather than a gift. For example, the donor might treat the offering as discharging a debt owed by the donor, or incurring a debt in the recipient for the donor's future profit. Considering the recipient to be virtuous and good, while ignoring their faults, involves considering the recipient as well-positioned to use offerings for good purposes. Hence, in treating their offering as a transaction rather than a gift, the donor judges others to be less valuable beneficiaries of whatever efforts the recipient might undertake by virtue of the donor's offering. But when, in comparing oneself to another, one judges oneself to be more valuable than others, one manifests conceit (P. mäna). Conceit is an impediment to wholesome living (see Dhammasangani III.5.1116; recited from Rhys Davids 1900, 298-299). Insofar as generous action facilitates wholesome living, no generous action manifests conceit. It follows that the offerings of generous actions are gifts rather than transactions. ${ }^{5}$

Whether the Giving Constraint and the Esteem Constraint are jointly sufficient conditions for generous action depends upon whether certain further conditions, regarding the donor's attitude toward their offering, are constraints on generous action or, instead, metrics for ranking the degree to which one generous action might be more generous than another generous action. Three such conditions are noteworthy. The first condition is Valued Giving.

Valued Giving: An individual gives a valued offering when, and insofar as, the same individual would value the offering as desirable were the individual to receive it. 
Miller endorses a similar condition as necessary for generous action, arguing that an action is generous only if "what is bestowed by the action is subjectively valued by the giver" (Miller 2018, 220). However, I remain uncertain whether the Pāli Buddhist tradition endorses Valued Giving.

De Silva quotes from an unnamed commentary on the Discourse with Kütadanta (Kütadanta Sutta, DN 5) that distinguishes two kinds of giver (P. dāyako) from the lordly giver (P. dānapti). ${ }^{6}$

He who himself enjoys delicious things but gives to others what is not delicious is a donor who is a slave to the gifts he gives. He who gives things of the same quality as he himself enjoys is one who is like a friend of the gift. He who satisfies himself with whatever he can get but gives delicacies to others is a lordly giver, a senior and master of the gifts given. (De Silva 2013, 116)

Because the Pāli Buddhist tradition tends to treat generous action as conducive to liberation from vice, giving a gift to which one is enslaved seems to disqualify the giving from being generous. Because one who is not enslaved to their gift is either a friend to their gift or a lordly giver, and because those who are friends to their gifts or lordly givers would value their gift as desirable were they to receive it, it seems to follow that Valued Giving is necessary for generous action. There is, however, some reason to doubt that giving a gift to which one is enslaved disqualifies the giving from being generous. In the Questions of King Milinda (Milinda Pañha), a monk Nāgasena convinces Milinda that anything is suitable as a gift when a worthy recipient is present (Book 4, Chapter 8, Section 7; recited from Rhys Davids 1894, 120-122).

And now, O king, tell me-is there anything in the world which should be withheld as a gift, and not bestowed, when one worthy of a gift, one to whom it is one's duty to give, is there? [...]

No, Sir. When faith arises in their hearts some give food to those worthy of gifts, and some give clothes, and some give bedding, and some give dwellings, and some give mats or robes ..., and some give the kingdom itself, and some give away even their own life. (Rhys Davids 1894, 120-122)

Those living in extreme poverty might have available, as gifts, only offerings they do not themselves enjoy, by virtue of lacking any enjoyable possessions. 
Such persons technically qualify as slaves to whatever gifts they might give. Since the Pāli Buddhist tradition treats them as capable of generous action nonetheless, the preceding commentary seems better interpreted as an effort to rank the degree to which generous actions are generous.

There is a second noteworthy condition of uncertain relevance as a constraint for generous action. The second condition is Confident Giving.

Confident Giving: An individual gives an offering with confidence when, and insofar as, the individual is confident that their offering will facilitate good outcomes for the recipient.

The Discourse on Eight Individuals (among other discourses) ranks worthy recipients for generous action. The Discourse about Kassapa (among other discourses) recommends giving to those who are maximally worthy. This provides some evidence for treating Confident Giving as necessary for generous action. For if Confident Giving is necessary for generous action, then knowing who is more or less worthy, and giving to those ranked as more highly worthy, is important for ensuring that one's giving-efforts are generous. However, the extension of worthiness to paradigmatically vicious persons, in the Compendium of Essence (and elsewhere), provides some evidence that Confident Giving is not necessary for generous action, because those who make their living by oppressing others are unlikely to change their ways upon receiving a gift. I remain unsure whether having esteem for those who make their living by oppressing others is compatible with believing that gifts to such persons are unlikely to facilitate good outcomes. If it is not, extending worthiness to paradigmatically vicious persons does not undermine the evidence for treating Confident Giving as a necessary condition for generous action. If it is, perhaps the correct conclusion is that generous action by one who gives with confidence is closer to being perfectly generous than generous action by one who lacks such confidence.

A third noteworthy condition provides some support for treating Confident Giving as a measure of the degree to which generous action is generous rather than as a necessary condition for generous action. The third condition is Responsive Giving.

Responsive Giving: An individual responsively gives an offering to a recipient 
when the individual gives whatever the recipient requests.

The Questions of King Milinda comes close to explicitly endorsing Responsive Giving as a necessary condition for generous action. Nāgasena is discussing with King Milinda a case in which another king, Vessantara, gave away his beloved wife and children as slaves to a priest (Book 4, Chapter 8, Section 5; recited from Rhys Davids 1894, 118-119). Milinda maintains that Vessantara's gift was excessive and cruel. Nāgasena responds that excessive giving is always good. He further responds that giving whatever the recipient requests, while substituting an alternative, is wrong. ${ }^{7}$

Insofar as generous action is always good, Nāgasena's response to Milinda seems to suggest that Responsive Giving is a necessary condition for generous action. To the extent that individuals might be confident that a requested gift will facilitate bad outcomes for the recipient, it follows that Confident Giving is not a necessary condition for generous action. I hesitate to endorse this line of reasoning, however, because the Pāli Buddhist tradition depicts Vessantara as a paradigm of perfect generosity. Perhaps those capable of perfectly generous action always oblige requests for gifts. This does not entail, however, that those who are unable to enact perfectly generous action always oblige requests for gifts. Perhaps imperfectly generous persons sometimes decline requests from others, preferring instead to give only when confident that their offering will facilitate good outcomes for the recipient. Such a preference might indicate an imperfect disposition for generosity. Since, however, some generous actions involve giving to recipients who make no requests, it cannot indicate that generous actions require Responsive Giving.

This concludes the elaboration for my proposed account of generous action in the Pāli Buddhist tradition. I now proceed to compare the proposal to extant contemporary Anglophone alternatives.

\section{Comparisons with Other Buddhist Accounts of Generous Action}

Contemporary English-language scholarship on Buddhist ethics identifies several characteristics of generous action. According to Wright,

The attitude of the giver and the spirit of the gift are essential to the practice 
of generosity. Calm and even-minded, the enlightened donor is not moved by anything but the welfare of human beings and the openness of heart entailed in noble giving. Therefore, no thought is given to the rewards or "fruit" that inevitably flow back to the donor from a genuine act of generosity. Although there will be rewards that are a natural consequence of an act of giving, focus on those "fruits" demean and undercut [sic] the act. (Wright 2009, 21)

According to Heim, "one should give out of high regard for a respected recipient, with a pleased mind and without ill will. A donor should give unquestioningly, cheerfully, and without looking for a weakness in the recipient" (Heim 2007, 196-197). According to Mackenzie,

The target or aim of generosity is the welfare of others, both mundane and spiritual. Generosity may involve giving material resources, protection, or healing to those in need.[...] Furthermore, the virtue of generosity is not just a matter of its aim; the mental state of the giver is central to the moral quality of the action. One must not only aim to benefit others, one must act from a spirit of generosity. The motivation of generosity involves the genuine desire to help, non-attachment to what one gives (including resources, time, or talents), and no expectation of reward. (MacKenzie 2018, 160-161)

These brief excerpts indicate that, from a Buddhist perspective, the one who enacts generous action, the donor, aims only to benefit others, and the donor pursues this aim by giving something to a recipient as a gift in a spirit of cheerful helpfulness. Because generous action, so understood, involves no expectation of reward or reciprocation, it is distinct from bartering and other economic transactions. Because generous action is unquestioning and insensitive to concerns about one's just deserts, it is distinct from justice. Insofar as charity involves encountering recipients as needy or inferior, generous action is also distinct from charitable action. ${ }^{8}$

Extant accounts of generous action in the Buddhist tradition succeed in demarcating generous action from bartering, just action, and charitable action. However, they do not identify characteristics of generous action that are distinctive for the Buddhist tradition. For example, Roberts and Wood maintain that generous action in the Christian tradition involves a donor giving a beneficial gift to a recipient spontaneously and in a spirit of gladness 
(Roberts and Wood 2007, 286-289). Both Hunt and Miller offer similar accounts from a secular perspective, replacing reference to spontaneity and gladness with a requirement that the donor not give from a sense of obligation (Hunt 1975; Miller 2018). Herzog and Price, similarly, define generous action as "giving good things freely to enhance the well-being of others" (Herzog and Price 2016, 4). Neither Christian nor secular accounts of generous action endorse the Esteem Constraint, which requires that generous donors have esteem for the recipients of their gifts. The account I propose of generous action in the Pāli Buddhist tradition improves upon extant accounts by virtue of making explicit this particular constraint, to which I turn in the next section. ${ }^{9}$

\section{The Value of Generous Action}

Extant accounts of generous action in the Buddhist tradition neglect the Esteem Constraint. This omission explains why these accounts ignore what is distinctive about the Pāli Buddhist approach to conceptualizing generous action. Extant accounts require, as an alternative constraint on generous action, that donors give with a pleased and cordial mind. Insofar as states of pleasant cordiality are valuable, this alternative focus helps to explain why generous actions are valuable. ${ }^{10}$

The account I propose supports a similar explanation. Giving with a pleased and cordial mind is a consequence of giving with esteem, or so I shall argue. This explanation, however, raises a puzzle. Giving with esteem also tends to have, as a consequence, certain expectations associated with merit. The puzzle is that expecting merit seems to preclude giving without an expectation of reward. I shall argue, to the contrary, that expecting merit does no such thing. Before doing so, however, I explain why those who give with esteem have a pleased and cordial mind.

The Discourse on the Six Factors of Giving (Chalangadana Sutta, AN 6.37) characterizes those who enact generous actions as glad in anticipation of giving, confident while giving, uplifted after giving, and throughout free of greed and hate.

Prior to giving one is joyful; while giving one settles the mind in trust; after giving one is elated: this is success in the act of offering. 
When they are devoid of lust [greed] and hatred, devoid of delusion, without taints, self-controlled, living the spiritual life, the field for the offering is complete....

Having performed such a charitable deed with a mind free from miserliness, the wise person, rich in faith, is reborn in a happy, non-afflictive world. (Bodhi 2012, 990)

The Pāli Buddhist tradition maintains that donors who give with esteem exhibit Selective Attention toward the recipient of their gift. By refraining from noticing the recipient's faults, the donor feels neither anger, envy, nor jealousy toward the recipient. This absence of negative feeling supports Confident Giving, whereby the donor is confident that their offering will facilitate good outcomes for the recipient. It also permits positive feelings to arise, such as pleasure in giving and cordiality toward the recipient (Heim 2004, 47).

The Pāli Buddhist tradition maintains that donors who give with esteem have a pleased and cordial mind partly by virtue of expecting merit for their generous action. In the Discourse on the Analysis of Gifts (Dakkbina Vibhanga Sutta, MN 142), the Buddha correlates the worthiness of a gift's recipient with the merit a donor can expect in return for their gift. The merit ranges from a hundred-fold return when giving to an animal to an immeasurable return when giving to one making progress toward the first stage of liberation (see also Adamek 2005, 139-140).

Ānanda, by giving a gift to an animal, the offering may be expected to repay a hundredfold. By giving a gift to an immoral ordinary person, the offering may be expected to repay a thousandfold. By giving a gift to a virtuous ordinary person, the offering may be expected to repay a hundred-thousandfold. By giving a gift to one outside [the Dispensation] who is free from lust for sensual pleasures, the offering may be expected to repay a hundred-thousand times a hundred-thousandfold.

By giving a gift to one who has entered upon the way to the realisation of the fruit of stream-entry, the offering may be expected to repay incalculably, immeasurably. What, then, should be said about giving a gift to a streamenterer? What should be said about giving a gift to one who has entered upon the way to the realisation of the fruit of once-return...to a once-returner... to one who has entered upon the way to the realisation of the fruit of non- 
return...to a non-returner...to one who has entered upon the way to the realisation of the fruit of arahantship...to an arahant...to a paccekabuddha? What should be said about giving a gift to a Tathāgata, accomplished and fully enlightened. (Ñāṇamoli and Bodhi 1995, 1104)

Wright summarizes the sorts of meritorious reward a generous donor might expect. He notes that rewards include "a share in the well-being of society as a whole [or a] slightly enhanced personal capacity to give in the future" as well as a sort of investment in the future that bestows "a better rebirth in the next life" (Wright 2009, 26-27; see also Adamek 2005, 144-149). These rewards support pleasure in giving, because they are desirable outcomes for the donor. They also support cordiality toward the recipient of giving, because the recipient's presence to the donor is a precondition for the donor acting in ways that earn their reward.

Expecting merit from generous action is puzzling. Since merit is a sort of reward, expecting merit from giving seems to preclude giving without an expectation of reward. This appearance, however, is deceptive. Insofar as generous giving neither incurs nor repays debt, it precludes expecting a reward from the recipients of gifts. This is consistent with expecting a reward from elsewhere, by virtue of the workings of karma. This second sort of expectation is the basis for the donor's expectation of reward. The source of merit is the giving itself rather than the recipient of the giving. So long as the donor performs their giving in the right manner, with esteem toward the recipient, their generous action earns good karma as merit. The good karma might return in the form of a favorable rebirth. It might return, as well, within the donor's lifetime as an ameliorating of hindrances such as greed and conceit.

Consider once again, by way of example, Indra's gift to Mahākassapa in the Discourse About Kassapa. Indra esteems Mahākassapa as a worthy disciple of the Buddha. He offers curried rice, which is a desirable, and valuable gift for someone like Mahākassapa, who is recovering from illness. In bestowing a gift that is likely to facilitate Mahākassapa's health, Indra can expect his offering to support Mahākassapa's efforts in developing the saingha. Insofar as the sangha helps to improve the lives of many others, Indra can be confident that his offering will facilitate good outcomes. Because a strong and vibrant sangha is likely to benefit Indra as well (through his associations with the sangha as a bodhisattva), and because Indra's action helps to improve his own morality, 
Indra also can expect his giving to return as a personal reward. Provided that esteem for Mahākassapa, rather than personal interest, motivates his giving, Indra's expectation of reward does not violate the Pāli Buddhist tradition's conditions for generous action.

\section{Esteem and the Teaching of No-Self}

Before proceeding to compare my proposed account of generous action in the Pāli Buddhist tradition to recent accounts of generous action from other philosophical traditions, I address an apparent tension, internal to Pāli Buddhism, between recommending generous action as virtuous, requiring that donors esteem the recipients of their generosity, and affirming that all sentient beings are empty of self. I do so by discussing, in turn, the teaching of no-self (P. anattā) in early Pāli discourses, the tension between this teaching and the proposed account of generous action, soteriological reasons for supposing that the tension is merely apparent, and a natural—albeit speculative-strategy for resolving the tension.

According to the Discourse on the Non-Self Characteristic (Anattalakkhana Sutta, SN 22.59), none of the constituents associated with persons are self (P. atta). The Buddha argues that none of the constituents associated with persons are selves, because each is subject to dukkha and dissolution (see Bodhi 2000a, 901-903). He thereby seems to conceptualize selves as loci of ownership and control, sources of sovereignty that are invulnerable to change and secure against undesirable influences from others. However, the Buddha does not deny that there are selves. This abstention from pronouncing upon matters of ontology is a recurring theme in the Pāli Buddhist tradition. For example, in Vacchagotta's Discourse on Fire (Aggi-Vacchagotta Sutta, MN 72), the Buddha, when pressed to answer various questions about the cosmos and the soul, declines to affirm any possible answer.

The speculative view that the world is not eternal...that the world is finite...that the world is infinite...that the soul and the body are the same...that the soul is one thing and the body another...that after death a Tathāgata exists...that after death a Tathāgata does not exist... that after death a Tathāgata both exists and does not exist...that after death a Tathāgata neither exists nor does not exist 
is a thicket of views, a wilderness of views, a contortion of views, a vacillation of views, a fetter of views. It is beset by suffering, by vexation, by despair, and by fever, and it does not lead to disenchantment, to dispassion, to cessation, to peace, to direct knowledge, to enlightenment, to Nibbāna. Seeing this danger, I do not take up any of these views. ${ }^{11}$ (Nānamamoli and Bodhi 1995, 591-592)

Similarly, in the Shorter Discourse With Mãlunikyaputta (Cülamālunkya Sutta, MN 63) the Buddha compares those who speculate about metaphysical matters to a man wondering about the qualities of a poison arrow lodged in his body, and he recommends attending to the removal of the arrow without regard to the arrow's history and composition (Ñānamoli and Bodhi 1995, 533-536).

There is, however, some evidence that the Pāli Buddhist tradition denies the existence of selves. For example, in the Discourse About Vajirä (Vajirā Sutta, SN 5.10), the eminent nun Vajirā is meditating beneath a tree. Wondering about the source and fate of her existence as a sentient being (P. satta), Vajirā lapses in her concentration when the malevolent demon Māra intervenes. Vajirā vanquishes Māra by affirming that, in considering herself as a sentient being, she is mistaken.

Why do you now assume 'a [sentient] being?' Māra, is that your speculative view? This is a heap of sheer formations. Here no [sentient] being is found. Just as, with an assemblage of parts, the word 'chariot' is used, so, when the aggregates exist, there is the convention 'a [sentient] being.' (Bodhi 2000a, 230)

Vajirā denies that she exists as a sentient being. Insofar as her insight generalizes and selves exists only if sentient beings exist, Vajirā thereby denies the existence of selves. ${ }^{12}$

Regardless of the Pāli Buddhist attitude toward the existence of selves, the tradition is clear that one ought to abstain from considering anything as a self. For example, in the Discourse on the Way to the Imperturbable (Annenja-Sappaya Sutta, MN 106), the Buddha instructs his students to consider wilderness, roots of trees, and empty dwellings as "void of a self or of what belongs to a self" (Ñānamoli and Bodhi 1995, 871). Similarly, in the Discourse With Girimananda (Girimananda Sutta, AN 10.60), the Buddha instructs Ānanda to consider his bodily senses, body, mind, mental states, and external happenings as not self (Bodhi 2012, 1412). This recommendation, however, seems to conflict with the 
Pāli Buddhist attitude toward generous action.

According to the analysis I propose for generous action in the Pāli Buddhist tradition, when a donor performs a generous action, the donor esteems the recipient of their gift (Esteem Constraint). Esteeming a recipient of a gift involves considering the recipient as an individual who is worthy of the gift. Insofar as considering someone as an individual who is worthy of a gift requires considering the individual as a self, it follows that recommending generous action as virtuous entails recommending that donors consider others as selves. But this is precisely what the Pāli discourses recommend against doing.

There is good reason to suppose that the tension between recommending generous action and endorsing the teaching of no-self is merely apparent. According to the Discourse on the Six Factors of Giving, generous actions are vehicles for ameliorating greed and hate in others. But they are also vehicles for ameliorating greed and hate in oneself. According to the Fire Sermon Discourse (Ädittapariyāya Sutta, SN 35.28), greed and hate are akin to burning fires (P. àditta) that sustain dukkha.

Bhikkhus [monks], all is burning. And what, bhikkhus, is the all that is burning? The eye is burning, forms are burning, eye-consciousness is burning, eyecontact is burning, and whatever feeling arises with eye-contact as conditionwhether pleasant or painful or neither-painful-nor-pleasant-that too is burning. Burning with what? Burning with the fire of lust [greed], with the fire of hatred, with the fire of delusion. (Bodhi 2000b, 1143)

In the Discourse on the Simile of the Quail (Latukikopama Sutta, MN 66), the Buddha recommends generous action as a vehicle for extinguishing these fires. Speaking to the monk Udāyin, the Buddha contrasts those who are attached by greed to routine and meager things with those who are not.

Udāyin, there are certain misguided men here who, when told by me 'Abandon this,' say: 'What, such a mere trifle, such a little thing as this? This recluse is much too exacting!' And they do not abandon that and they show discourtesy towards me as well as towards those bhikkhus desirous of training. For them that thing becomes a strong, stout, tough, unrotting tether and a thick yoke....

So, too, Udāyin, there are certain clansmen here who, when told by me 'Abandon this'...abandon that and do not show discourtesy towards me or 
towards those bhikkhus desirous of training. Having abandoned it, they live at ease, unruffled, subsisting on others' gifts, with mind [as aloof] as a wild deer's. For them that thing becomes a feeble, weak, rotting, cordless tether. (Ñannamoli and Bodhi 1995, 553-554)

Generous actions, accordingly, are vehicles to ameliorate $d u k k b a$, and those who aim to ameliorate dukkha ought to perform generous actions. Yet the Pāli Buddhist tradition is also clear that those who aim to ameliorate $d u k k b a$ also ought to abstain from considering anything as a self. For endorsing the existence of selves fuels the fire of delusion (P. moha), and this fire also sustains dukkha. Insofar as extinguishing one fire does not involve fueling or creating another, it follows that extinguishing greed and hate through generous action is consistent with extinguishing delusion through following the teaching of no-self.

Unfortunately, the Pāli Buddhist tradition offers no explicit approach to resolving the apparent tension between recommending generous action and endorsing the teaching of no-self. I speculate, on behalf of the tradition, that one way to resolve the tension is to deny that considering someone as an individual who is worthy of a gift requires considering the individual as a self. The Pāli Buddhist tradition seems to indicate that to consider someone as a self is to consider them as having ownership or control over themselves and their constituents. By contrast, following a recent analysis of biological individuality by Pradeu (2010), I propose that to consider someone as an individual is to consider them as having spatial and temporal boundaries that suffice well enough to distinguish them from their surroundings and to permit demonstrative reference (with phrases such as "this one here" or "that one there"). This proposal entails that considering someone as an individual does not require considering them as a self. For just as one might consider an individual cloud as distinct from other clouds in the sky without considering the cloud as owning or controlling its water vapors, and just as one might consider a school of tuna fish as an individual distinct from predatory sharks without considering the school itself as owning or controlling its constituent fish, donors might consider recipients of their giving as individuals who are distinct from others without considering the recipients as owning or controlling themselves.

One might object that considering someone as an individual without considering them as a self precludes considering them as worthy of receiving 
a gift. There are two ways to develop this objection. The first is to contend that considering something to be worthy requires considering it to be a self. There is good reason to suppose that the Pâli Buddhist tradition rejects this contention. In his analysis of early Buddhist ecology, Kabilsingh notes that the attitude of the Buddha and his followers to forests and trees "cannot be interpreted otherwise than as an appreciation of their spiritual worth and the desire by believers to conserve them" (Kabilsingh 1998, 59). Hrynkow notes, as well, that early Buddhists consistently consider trees to be worthy of conservation (Hrynkow 2017, 807). The same Buddhists likely also consider trees to be sentient and, perhaps, inhabited by divine spirits (Schmithausen 1991,5-8). ${ }^{13}$ But insofar as the concern to conserve trees derives from a concern to prevent harm, and insofar as selves would be invulnerable to harm were they to exist, neither trees nor the spirits within qualify as selves.

The second way to develop the preceding objection is to contend that receiving a gift involves coming to own the gift. Since ownership is impossible in the absence of a self, it follows that considering a recipient as a selfless individual precludes considering them as someone capable of receiving a gift. I offer two responses to this version of the objection. The first is that considering someone to be a worthy gift recipient does not require considering them to be capable of receiving the gift. For example, universities sometimes offer scholarships to potential students without regard for whether mitigating factors might prevent those students from accepting the scholarships. Similarly, a layperson might consider a monk to be worthy of receiving a donation of rice without also considering whether the monk has undertaken a period of fasting.

The second response to the second version of the preceding objection is that, when properly understood, the teaching of no-self denies that receiving something from another involves coming to own it. The recommendation to abstain from considering anything to be a self derives from the teaching that everything arises in dependence upon others (P. paticcasamuppäda). For selves, as loci of ownership and control, are individuals whose fates do not depend upon others. Yet insofar as individuals always depend upon others, they lack power to keep whatever they might have. ${ }^{14}$ They receive from others without thereby owning what they receive. So, too, in the case of generous action. Beneficiaries of generous action receive gifts from donors, but they do not own those gifts. Hence, abstaining from considering others as selves does not preclude considering them as capable of receiving a gift, because abstaining from 
considering others as selves is consistent with denying that gift giving involves transfer of ownership.

\section{Cross-Cultural Connections}

Miller concludes his (secular) analysis of generous action with a list of open questions for future research (Miller 2018, 243). For the sake of facilitating cross-cultural dialogue, I proceed to examine how the preceding account of generous action in the Pāli Buddhist tradition bears upon a selection of Miller's questions. I focus on conceptual questions about generous action. In doing so, I overlook questions Miller asks about his own account, empirical research, and methodological issues. (These include, respectively, Miller's first, second, and fourth questions, eighth and ninth questions, and tenth question.) I overlook, as well, one question the Pāli Buddhist tradition does not clearly address, or at least the answer to which is not apparent from the preceding analysis. (This is Miller's fifth question: "What should be said about gifts in which what is given ... is itself ill begotten?") These restrictions narrow the field of questions from ten to three.

Consider, first, Miller's third question:

(iii) Are there any requirements pertaining to recipients of acts of putative generosity — for instance, that they be disposed to welcome such acts?

The Pāli Buddhist account of generous action I propose imposes no conditions on the recipient of a donor's offering. The account requires that the recipient be someone who, from the perspective of the donor, is worthy of receiving an offering. However, insofar as all sentient beings are worthy, this first requirement is best understood as pertaining to the donor's subjective attitude rather than the recipient's objective worthiness. In traditional Buddhist cultures, there tends to be an expectation that recipients put offerings received to good use. The standard rationale for this expectation is that it helps donors to have confidence that their offerings will facilitate good outcomes for recipients of their gifts. However, this expectation does not qualify as a requirement on generous action, because generous action (on the account I propose) requires donors to ignore faults in recipients that might interfere with the recipients putting offerings to good use. 
Consider, next, Miller's sixth question:

(vi) Is a wholeheartedness requirement a plausible necessary condition, such that when acting from generosity, a person must not have conflicting motives to both help and not help?

Miller tentatively endorses Wallace's answer to this question, according to which a generous person "gives freely, wanting to give, with no practice in the background that requires such giving" (Miller 2018, 243 no. 44; citing Wallace 1978, 151). The Pāli Buddhist account of generous action I propose agrees only in part. Consider the Discourse About Kassapa. The requirement that Indra esteem Mahākassapa precludes Indra not wanting to help Mahākassapa. Yet the discourse also characterizes Indra as having a duty to make merit. Insofar as duties are binding, the practice of merit-making requires Indra to give to Mahākassapa. Yet the same discourse also conceptualizes the motivation for Indra's generous action as his esteem for Mahākassapa rather than his desire to satisfy a duty. Indra invokes a duty to give in the context of explaining why his offering is permissible. This is consistent with Indra having, as his motive for giving, a desire to facilitate good outcomes for one who is a worthy recipient.

Consider, lastly, Miller's seventh question:

(vii) What does cross-cultural analysis reveal about the plausibility of the account, and in general about the universality of various claims about generosity?

The Pāli Buddhist account of generous action I propose agrees with Miller's account. Both accounts entail that generous action differs from bartering, just action, and charitable action. Both accounts entail, as well, that donors enacting generous action should aim only to benefit the recipients of their giving, that they should pursue this aim by giving something to a recipient as a gift in a spirit of cheerful helpfulness, and that their gift should be something they judge to be valuable.

The account I propose differs from Miller's in two noteworthy ways. First, the account I propose, but not Miller's, denies that generous action must be supererogatory. Miller justifies his supererogation requirement with a brief 
argument: "Gifts by their nature are not things one is required to bestow on a recipient. They are freely chosen, praiseworthy if bestowed, but not blameworthy if omitted" (Miller 2018, 227). I understand the Pāli Buddhist tradition to endorse an alternative analysis of gifts. This alternative analysis contrasts gifts with things one bestows on a recipient for the sake of receiving a reward or return. Miller cites Sanchez's analysis of gifts, according to which one gives a gift only if "one's giving does not depend on whether or not one receives anything in return for one's gift" (Sanchez 2010, 443). Sanchez's analysis does not support Miller's supererogation requirement. Indra's generous action in the Discourse About Kassapa is required by duty. Yet, insofar as his esteem for Mahākassapa, rather than his duty, motivates his giving, Indra's giving does not depend upon receiving anything in return for his gift. Miller also mentions, as support for his supererogation requirement, two fictional case studies of his own devising. By stipulation, there is no requirement that the donors in Miller's cases give to another (Miller 2018, 217-218). Yet the cases demonstrate, at best, that some generous actions are supererogatory. The case of Indra, from the Discourse About Kassapa, shows that generous actions required by duty need not have, as their motive, a sense of duty.

The second noteworthy way in which the account of generous action I propose differs from Miller's account is its requirement that donors esteem the recipients of their giving. Approaches to generous action with Indic ancestry tend to endorse a similar requirement. ${ }^{15}$ Secular accounts, by contrast, tend to focus on connections between generous action and empathy for others (see Miller 2018, 226; Allen 2018, 29-30). Empathy is akin to esteem. Both involve responding in some way to another. The response in empathy involves coming to have an emotional state that is similar to another's emotional state. The response in esteem, by contrast, involves coming to have a cognitive state that evaluates another as superior in virtue and goodness. Esteeming another does not require empathizing with them. Moreover, Indic traditions tend to associate empathy (or compassion) with charitable action rather than generous action. ${ }^{16}$ Empathy motivates charitable giving to the needy, by making the donor responsive to the plight of the needy. Esteem, by contrast, involves encountering those in need as worthy of offerings, not because they lack necessities, but because they possess worthiness. The significance of this difference, between accounts supposing that generous actions involve encountering others as lacking something valuable, and accounts supposing 
that generous actions involve encountering others as having something valuable, is a topic I leave for further research.

\section{Concluding Reflections}

Despite the importance of generosity to Buddhist teachings, the Pāli Buddhist tradition offers no explicit account of generous action. I address this omission by proposing that, according to the Pāli Buddhist tradition, generous actions are instances of giving in which a donor esteems the recipient of their giving. I propose, as well, that esteeming someone involves (subjectively) encountering them as (objectively) superior in virtue and goodness while refraining from noticing their faults. These proposals demarcate generous action from bartering, just action, and charitable action. They also explain why generous donors, when giving, have pleased and cordial minds.

I support my proposals with textual evidence from Pāli Buddhist discourses. However, these proposals seem to conflict with teachings about merit and noself from other Pāli Buddhist discourses. Expecting merit from an action seems to preclude giving generously, without an expectation of reward. Esteeming others seems to require considering them as selves. I argue, to the contrary, that these appearances are deceptive. Performing a generous action is consistent with expecting merit from that action, provided the merit is expected to accrue from the workings of karma rather than from a recipient's reciprocity. Esteeming the recipients of gifts is also consistent with not considering them as selves, provided the recipients and their gifts are considered to be dependently arisen. Accordingly, in addition to highlighting some ways in which the Pāli Buddhist conception of generous action differs from conceptions of generous action from other traditions, my proposed account of generous action reveals some of the subtle relations, within the Pāli Buddhist tradition, between teachings about generosity, merit and karma, no-self and dependent arising. 


\section{Notes}

* Acknowledgement: I thank my anonymous referees for their generous and constructive feedback, and especially for the recommendation to consider the connection between esteem and the teaching of noself.

I also thank Drs. KIM Jongwook, Richard D. McBride II, and Sung-Eun T. KIM for the meticulous editorial assistance.

1 In this paper I employ the following abbreviations: P. for Pali, Skt. for Sanskrit, and Ch. for Chinese.

2 For further discussion of esteem in Indian Buddhism, see Heim (2004, 45-53). The standard translation of the Chinese character for esteem, xin 信, is faith. However, in Buddhist contexts, esteem is consistent with, and perhaps requires, the exercise of discursive judgment for determining worthiness. See Gómez $(2004,278)$.

3 I qualify an individual's encounter of another as subjective to allow that the individual need not be correct in their evaluation of the one being encountered. I qualify the evaluative content of an individual's encounter of another as objective when the individual considers their evaluation to be more than a matter of preference or custom.

4 For further discussion of this story, see Heim (2004, 50-51).

5 For further discussion of donor expectations in the context of generous action, see Heim (2004, 33-35).

6 For an English translation of the Discourse with Kütadanta, see Walshe (1995, 133-141).

7 The priest had requested the king's family as a gift. Nāgasena denies that the king's gift was cruel, because Vessantara knew that his father would ransom the family back from slavery (see Questions of King Milinda 4.8.17; recited from Rhys Davids 1894,131).

8 For further discussion in relation to Christian charity, see Heim (2004, 155 n. 77).

9 Heim (2004) and Heim (2007) connect esteem with Buddhist generosity. However, neither Heim (2004) nor Heim (2007) posit esteem as a necessary condition for generous action.

10 For a more comprehensive list of why the Pāli Buddhist tradition treats generous actions as valuable, see De Silva (2013,123-127).

11 The Buddha's responses to Vacchagota seem to be jointly inconsistent. For an analysis of the Buddha's responses that removes this inconsistency, see Jones (2020).

12 For further discussion of Vajirā’s reasoning, see Jones (forthcoming).

13 When explaining why early Buddhist tradition prohibits monks from killing trees and other plants, Schmithausen notes, "one could add the idea that trees deserve gratitude for the service they render people, esp. offering shade and fruits.... This idea need not imply that the tree is actually regarded as a sentient being, but at least it is treated as if it were one, i.e., like a friend or partner" (Schmithausen 1991, 7 no. 38).

14 Rose makes the same point with more poetic language: "We are only temporary caretakers of all that is provided; essentially, we own nothing. As this understanding takes 
root in us, there is no getting, possessing, and giving; there is just the spaciousness that allows all things to remain in the natural flow of life" (Rose 2012,12).

15 For details, see Heim (2004, 45-53).

16 For details, see Heim (2004, 76-78). 


\section{Abbreviations}

$\begin{array}{ll}\text { AN } & \text { An̈guttara Nikāya } \\ \text { DN } & \text { Dïgha Nikāya } \\ \text { MN } & \text { Majjhima Nikāya } \\ \text { SN } & \text { Samyutta Nikāya } \\ \text { Ud } & \text { Udāna }\end{array}$

\section{References}

Adamek, Wendi L “The Impossibility of the Given: Representations of Merit and 2005 Emptiness in Medieval Chinese Buddhism." History of Religions 45(2): 135-180. https://doi.org/10.1086/502698

Allen, Summer 2018 The Science of Generosity. Berkeley: Greater Good Science Center.

Aung, Shwe Zan Points of Controversy or Subjects of Discourse: Being a Translation of and Caroline A.F. the Kathä-Vatthu from the Abhidhamma-Pitaka. London: Pali Text Rhys Davids, Society.

trans. 1915

Bodhi, Bhikkhu, The Connected Discourses of the Buddha: A New Translation of the trans.2000a Samyutta Nikàya, Volume I. Boston: Wisdom Publications.

trans.2000b The Connected Discourses of the Buddha: A New Translation of the Samyutta Nikàya, Volume II. Boston: Wisdom Publications.

trans. 2012 The Numerical Discourses of the Buddha: A Translation of the Anguttara Nikàya. Boston: Wisdom Publications.

De Silva, Lily "Giving in the Pali Canon." In Collected Wheel Publications Volume 2013 XXIV: Numbers 362 to 376, 115-127. Kandy: Buddhist Publication Society.

Gómez, Luis O. “Faith.”In Encyclopedia of Buddhism, Volume One: A-L, ed. Robert E. 2004 Buswell, Jr., 277-279. New York: Thomson Gale.

Goodman, Charles "Virtue in Buddhist Ethical Traditions." In The Routledge 2015 Companion to Virtue Ethics, eds. Lorraine Besser-Jones and Michael Slote, 89-98. New York: Routledge. 
Heim, Maria Theories of the Gift in South Asia: Hindu, Buddhist, and Jain Reflections on 2004 Dāna. New York: Routledge. https://doi.org/10.4324/ 9780203502266

2007 “Dāna as a Moral Category.” In Indian Etbics: Classical Traditions and Contemporary Challenges, Volume I, eds. Purushottama Bilimoria, Joseph Prabhu, and Renuka Sharma, 191-209. Burlington, VT: Ashgate.

Herzog, Patricia American Generosity: Who Gives and Why. New York: Oxford University Snell Press. https://doi.org/10.1093/acprof:oso/ 9780190456498.001. and Heather E. Price 0001

2016

Hrynkow, "Nature Worship (Buddhism).” In Buddhism and Jainism, eds. K. Christopher T. S. Sarao and Jeffery D. Long, 806-808. Dordrecht: Springer 2017 Nature. https://doi.org/10.1007/978-94-024-0852-2_289

Hunt, Lester H. “Generosity.” American Philosophical Quarterly 12(3): 235-244.

1975

Ireland,John, The Udana: Inspired Utterances of the Buddha \& The Itivuttaka: The trans. 1997 Buddha's Sayings. Kandy: Buddhist Publication Society.

Jones, Nicholaos "A Russellian Analysis of the Buddhist Catuṣkoți." Comparative 2020 Philosophy 11(2): 63-89. https://doi.org/10.31979/2151-6014 (2020).110206

Forthcoming "Mereological Composition in Analytic and Buddhist Perspective." Journal of the American Philosophical Association.

Kabilsingh, Buddhism and Nature Conservation. Bangkok: Thammasat Chatsumarn University Press.

1998

Keown, Damien The Nature of Buddhist Ethics. New York: Palgrave Macmillan. 1992 https://doi.org/10.1007/978-1-349-22092-2.

MacKenzie, "Buddhism and the Virtues." In The Oxford Handbook of Virtue, Matthew ed. Nancy E. Snow, 153-170. New York: Oxford University Press. 2018 https://doi.org/10.1093/oxfordhb/9780199385195.013.18 
Miller, Christian B. "Generosity: A Preliminary Account of a Surprisingly Neglected 2018 Virtue.” Metaphilosophy 49(3): 216-245. https://doi.org/10.1111/ meta. 12298

Nānamoli, Bhikkhu The Middle Length Discourses of the Buddha: A New Translation of the and Bhikkhu Bodhi, Majjhima Nikāya. Kandy: Buddhist Publication Society.

trans. 1995

Ohnuma, Reiko Buddhist Head, Eyes, Flesh, and Blood: Giving Away the Body in 2007 Indian Literature. New York: Columbia University Press. https:// doi.org/10.7312/ohnu13708

Perry, "Indra in the Rig-Veda." Journal of the American Oriental Society 11:

Edward Delavan 117-208. https://doi.org/10.2307/592191

1885

Pradeu, Thomas "What is an Organism? An Immunological Answer." History and 2010 Philosophy of the Life Sciences 32(2/3): 247-267.

Rhys Davids, A Buddhist Manual of Psychological Ethics of the Fourth Century B.C.

Caroline A. F. London: Royal Asiatic Society. 1900

Rhy Davids, T.W., The Questions of King Milinda. Oxford: Clarendon Press. trans. 1894

Roberts, Robert C. Intellectual Virtues: An Essay on Regulative Epistemology. New York: and W. Jay Wood Oxford University Press. https://doi.org/10.1093/acprof:oso/ 20079780199283675.003 .0001

Rose, Marcia “The Gift that Cannot Be Given: Q \& A with Marcia Rose.” In 2012 Tricycle Teachings: Generosity, 11-13. Tricycle. https://tricycle.org/ ebooks/tricycle-teachings-generosity/

Sanchez, "Generosity: Variations on a Theme from Aristotle to Levinas." The Carlos Alberto Heythrop Journal 51(3): 442-453. https://doi.org/10.1111/j.1468$2010 \quad$ 2265.2009.00480.x

Schmithausen, Buddhism and Nature. Tokyo: The International Institute for Lambert Buddhist Studies. 1991 
Wallace, James Virtues and Vices. Ithaca: Cornell University Press.

1978

Walshe, Maurice The Long Discourses of the Buddha: A Translation of the Digha Nikaya. 1995 Boston: Wisdom Publications.

Wright, Dale S. The Six Perfections: Buddhism and the Cultivation of Character. New 2009 York: Oxford University Press. 